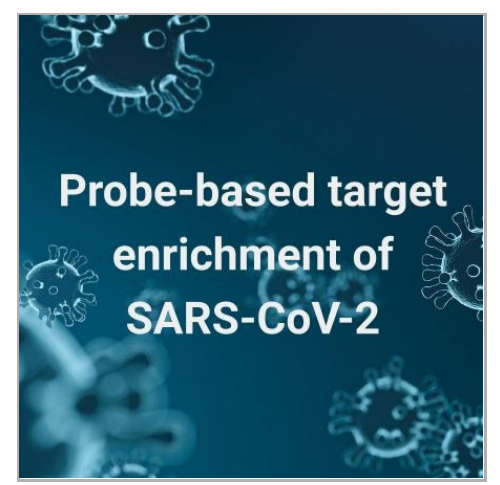

APR 02, 2020

\section{(3) Probe-based target enrichment of SARS-CoV-2}

\section{Mariateresa De Cesare ${ }^{1}$}

${ }^{1}$ Welcome Centre for Human Genetics, University of Oxford

\section{Coronavirus Method Development Community COG-UK}

Mariateresa de Cesare

Wellcome Centre for Human Genetics, Human Technopole

\section{OPEN $\odot$ ACCESS}

\section{DOI:}

dx.doi.org/10.17504/protocol s.io. bd5di826

Protocol Citation: Mariateres a De Cesare 2020. Probebased target enrichment of SARS-CoV-2. protocols.io https://dx.doi.org/10.17504/p rotocols.io.bd5di826

\section{MANUSCRIPT CITATION:}

David Bonsall, Tanya Golubchik, Mariateresa de Cesare, Mohammed Limbada, Barry Kosloff, George MacIntyre-Cockett, Matthew Hall, Chris Wymant, Azim Ansari, Lucie AbelerDörner, Ab Schaap, Anthony Brown, Eleanor Barnes, Estelle Piwowar-Manning, Susan Eshleman, Ethan Wilson, Lynda Emel, Richard Hayes, Sarah Fidler, Helen Ayles, Rory Bowden, Christophe Fraser, and The HPTN 071 (PopART) team, A comprehensive genomics solution for HIV surveillance and clinical monitoring in low income settings, J Clin Mic (Accepted)

License: This is an open access protocol distributed under the terms of the Creative Commons Attribution License, which permits unrestricted use, distribution, and reproduction in any medium, provided the original author and source are credited 
Protocol status: Working We use this protocol and it's working

Created: Mar 23, 2020

Last Modified: Apr 02, 2020

PROTOCOL integer ID: 34693

Keywords: SARS-CoV-2, SARS, Covid-19, Corona, 2019-nCoV, sequencing
ABSTRACT

- Viral RNA library prep using SMARTer Stranded Total RNA-Seq Kit v2 - Pico Input Mammalian followed by a probe-based bait capture (SeqCap, Roche and $x$ Gen, IDT) to generate tagged enriched viral libraries from total RNA that retain directionality in the library.

- The SMARTer Stranded kit uses random primers, tailed with Illumina Read1 sequence, to start reverse transcription, and a Template Switching Oligo (TSO) to add Read2 sequence at the $3^{\prime}$ of the synthesized cDNA. The $1^{\text {st }}$ stranded cDNA is then amplified using Indexed primers to generate in one step $2^{\text {nd }}$ strand cDNA and complete tagged Illumina libraries.

- Pooled libraries undergo target enrichment using custom virus-specific biotinylated probes to capture cDNA derived from viral RNA present in the sample.

- This method has been optimized for large scale viral sequencing projects, and up to $2 \times 96$-well RNA plates can be prepped in parallel.

- The protocol follows "Option $\mathbf{2}$ (without fragmentation)" workflow of the kit User Manual for library preparation, with $1 / 4$ of the recommended reaction volume for denaturation and CDNA synthesis, and $1 / 2$ for PCR, all steps done in 384-well plates.

NOTE: the kit contains a Ribodepletion PCR-based module not used in this protocol, so PCR reagents are in excess and a higher volume for PCR can be used safely without depleting the kit of reagents unevenly.

- The absence of an RNA fragmentation step coupled with more stringent cleanups (at $0.68 x$ ) generates libraries with longer insert size, therefor this protocol is only to be used on RNA samples of high quality, and unnecessary freeze-thaw of the RNA MUST be avoided. As the RNA extracted from plasma/swabs is below the detection level for QC, if in doubt about the quality of the RNA provided, proceed with library preparation and pooling, but check the size of the libraries before cleanup of the pool as the $0.68 \mathrm{X}$ beads ratio recommended in this protocol would remove most of the library if the starting RNA is of lower quality.

- To maximize RNA input and improve sensitivity of the assay, an RNA concentration step at the start of the procedure has been added, though not necessary to generate libraries.

\section{ATTACHMENTS}

Sequencing_COVID-

19_target_enrichment.pdf

\section{GUIDELINES}

Timeframe 
The protocol can be completed in 2-3 days, depending on the length of the hybridization time: if the capture is set up overnight on Day 1 , it can be completed on Day2.

If there is not enough time to start the capture on Day1, set up the capture early on Day2 and hybridize for $4 \mathrm{~h}$ : mind that once the hybridization is stopped, all following steps prior to LM-PCR must be completed!

\section{Note}

NOTE: The time to dry with the SpeedVac the libraries pooled on Day1 is variable and dependent on the volume of the pool and could take $>>1 \mathrm{~h}$

Day1: Library prep with pooling, cleanup and QC; +/-set up for O/N capture

Day2: Capture; $10 \mathrm{nM},+/-$ qPCR

\begin{tabular}{|c|c|c|}
\hline \multirow{10}{*}{ Day1 } & Step & $\begin{array}{l}\text { Estim } \\
\text { ated } \\
\text { time }\end{array}$ \\
\hline & $\begin{array}{l}\text { Prepa } \\
\text { ration }\end{array}$ & $\begin{array}{l}30 \\
\text { minut } \\
\text { es }\end{array}$ \\
\hline & $\begin{array}{l}\text { RNA } \\
\text { conce } \\
\text { ntrati } \\
\text { on }\end{array}$ & $\begin{array}{l}30 \\
\text { minut } \\
\text { es }\end{array}$ \\
\hline & $\begin{array}{l}\text { cDNA } \\
\text { synth } \\
\text { esis } \\
\text { setup }\end{array}$ & $\begin{array}{l}10 \\
\text { minut } \\
\text { es }\end{array}$ \\
\hline & $\begin{array}{l}\text { cDNA } \\
1 \text { st } \\
\text { stran } \\
\text { d } \\
\text { synth } \\
\text { esis }\end{array}$ & $\begin{array}{l}1 \mathrm{~h} 40 \\
\text { minut } \\
\text { es }\end{array}$ \\
\hline & $\begin{array}{l}\text { PCR } \\
\text { setup }\end{array}$ & $\begin{array}{l}15 \\
\text { minut } \\
\text { es }\end{array}$ \\
\hline & PCR & $\begin{array}{l}35 \\
\text { minut } \\
\text { es }\end{array}$ \\
\hline & $\begin{array}{l}\text { Poolin } \\
\text { g by } \\
\text { volum } \\
\text { e }\end{array}$ & $\begin{array}{l}10 \\
\text { minut } \\
\text { es }\end{array}$ \\
\hline & \begin{tabular}{|l|} 
Pool \\
clean \\
up
\end{tabular} & \begin{tabular}{|l}
30 \\
minut \\
es
\end{tabular} \\
\hline & $\mathrm{QC}$ & $\begin{array}{l}15 \\
\text { minut } \\
\text { es }\end{array}$ \\
\hline
\end{tabular}




\begin{tabular}{|c|c|c|}
\hline \multirow{2}{*}{$\begin{array}{l}\text { Optio } \\
\text { nal } \\
\text { Day1 } \\
\text { or } \\
\text { Day2 }\end{array}$} & $\begin{array}{l}\text { Spee } \\
\text { dVac } \\
\text { drying } \\
\text { of } \\
\text { pool }\end{array}$ & $\begin{array}{l}20 \\
\text { minut } \\
\text { es- } \\
1.5 \\
\text { hours }\end{array}$ \\
\hline & $\begin{array}{l}\text { Captu } \\
\text { re } \\
\text { setup }\end{array}$ & \begin{tabular}{|l}
20 \\
minut \\
es
\end{tabular} \\
\hline \multirow{8}{*}{ Day2 } & $\begin{array}{l}\text { Probe } \\
\text { Hybri } \\
\text { dizati } \\
\text { on }\end{array}$ & \begin{tabular}{|l}
4 \\
hours \\
(or \\
overni \\
ght)
\end{tabular} \\
\hline & $\begin{array}{l}\text { Prepa } \\
\text { ration } \\
\text { of } \\
\text { strept } \\
\text { avidin } \\
\text { beads } \\
\text { and } \\
\text { wash } \\
\text { buffer } \\
\text { s }\end{array}$ & $\begin{array}{l}15 \\
\text { minut } \\
\text { es }\end{array}$ \\
\hline & $\begin{array}{l}\text { Hybri } \\
\text { dizati } \\
\text { on to } \\
\text { strept } \\
\text { avidin } \\
\text { beads }\end{array}$ & $\begin{array}{l}45 \\
\text { mins }\end{array}$ \\
\hline & $\begin{array}{l}\text { Strept } \\
\text { avidin } \\
\text { wash } \\
\text { es } \\
\text { and } \\
\text { PCR } \\
\text { setup }\end{array}$ & $\begin{array}{l}20 \\
\text { mins }\end{array}$ \\
\hline & $\begin{array}{l}\text { Post- } \\
\text { Captu } \\
\text { re } \\
\text { LM- } \\
\text { PCR }\end{array}$ & $\begin{array}{l}35 \\
\text { mins }\end{array}$ \\
\hline & $\begin{array}{l}\text { Captu } \\
\text { re } \\
\text { clean } \\
\text { up }\end{array}$ & $\begin{array}{l}30 \\
\text { minut } \\
\text { es }\end{array}$ \\
\hline & $\mathrm{QC}$ & $\begin{array}{l}15 \\
\text { mins }\end{array}$ \\
\hline & $\begin{array}{l}\text { qPCR } \\
\text { setup }\end{array}$ & $\begin{array}{l}30 \\
\text { minut } \\
\text { es }\end{array}$ \\
\hline & qPCR & $\begin{array}{l}1.5 \\
\text { hours }\end{array}$ \\
\hline
\end{tabular}

\section{References}

Supplementary Documents:

- Library Preparation - Takara-Clontech, SMARTer Stranded Total RNA-Seq Kit v2 
- Pico Input Mammalian

- Roche, SeqCap EZ Library SR

\section{MATERIALS}

\section{MATERIALS}

88 Qubit@ dsDNA HS Assay Kit Thermo Fisher Scientific Catalog \#Q32854

89 High Sensitivity D5000 ScreenTape Agilent Technologies Catalog \#50675592

88 High Sensitivity D5000 Reagents Agilent Technologies Catalog \#5067-5593

88 High Sensitivity D1000 Reagents Agilent Technologies Catalog \#5067-5584

88

High Sensitivity D1000 ScreenTape Agilent Technologies Catalog \#50675584

88 SeqCap EZ Hybridization and Wash Kit Roche Catalog \#5634253001

89 SMARTer Stranded Total RNA-Seq Kit v2 - Pico Input

Mammalian Takara Catalog \#634418

XGen® Universal Blockers-TS Mix 96 rxn Integrated DNA

Technologies Catalog \#1075475

88 NG SeqCap EZ Accessory Kit V2 Roche Catalog \#7145594001

88 RNAClean XP Kit Beckman Coulter Catalog \#A66514

88 AMPure XP Beckman Coulter Catalog \#A63881

88 High Sensitivity D5000 Ladder Agilent Technologies Catalog \#5067-5594

88 High Sensitivity D1000 Ladder Agilent Technologies Catalog \#5067-5587

88 Dynabeads $^{\text {TM }}$ M-270 Streptavidin Thermo Fisher Scientific Catalog \#65305

Note

Store

- SMARTer® Stranded Total RNA-Seq Kit v2 - Pico Input Mammalian at $8^{\circ}-20^{\circ} \mathrm{C}$

- SMART TSO Mix v2 (from SMARTer® Stranded Total RNA-Seq Kit v2) at $8^{\circ}-80^{\circ} \mathrm{C}$

- NG SeqCap EZ Accessory Kits v2 at $8^{\circ}-20^{\circ} \mathrm{C}$

- SeqCap Hybridization and Wash Kit at $8^{\circ}-20^{\circ} \mathrm{C}$

- Dynabeads ${ }^{\mathrm{TM}} \mathrm{M}-270$ Streptavidin at $8^{\circ} 4{ }^{\circ} \mathrm{C}$

\section{Required Content of the Kits:}

Takara-Clontech, SMARTer Stranded Total RNA-Seq Kit v2 - Pico Input Mammalian

- SMART TSO Mix v2 (Cat\#: ST1250) 
- SMART Pico Oligos Mix v2 (Cat\#: ST1262)

- 5X First-Strand Buffer (Cat\#: ST1266)

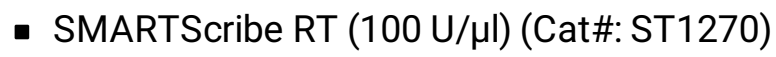

- RNase Inhibitor (40 U/ $\mathrm{\mu l})$ (Cat\#: ST1272)

- SeqAmp DNA Polymerase (Cat\#: ST1280)

- SeqAmp CB PCR Buffer (2X) (Cat\#: ST1282)

- Nuclease-Free Water

- Tris Buffer (5 mM) (Elution Buffer, EB)

SeqCap Hybridization and Wash Kit (Cat\#: 5634253001)

- 10X SC Wash Buffer I (Vial 1)

- 10X SC Wash Buffer II (Vial 2)

- 10X SC Wash Buffer III (Vial 3)

- 10X Stringent Wash Buffer (Vial 4)

- 2x Hybridization Buffer (Vial 5)

- Hybridization Component A (Vial 6)

- 2.5X Bead Wash Buffer (Vial 7)

SeqCap EZ Accessory Kits v2 (Cat\#: 07145594001)

- COT-1 Human DNA

- Water, DNA Grade

- KAPA HiFi HotStart ReadyMix

- Post- LM-PCR Oligos 1 \& 2

\section{Additional Reagents}

- IDT xGen ${ }^{\circledR}$ Lockdown Probes

\section{Equipment}

- Gilson Platemaster

- Pipetman Diamond Tips DF30ST Tipack (Gilson, F171303)

- Pipetman Diamond Tips DF200ST Tipack (Gilson, F171503)

- Invitrogen, DynaMag-2 Magnet (Cat\#: 123-21D)

- 384 block Thermocycler

- DNA Vacuum Concentrator

- Heat block

- Single and multi-channel pipettes with tips, 2-1000 $\mu \mathrm{l}$

- Qubit® 3.0 Fluorometer (Q33216)

- Tapestation 2200

- $1.5 \mathrm{ml}$ LoBind tubes 
- $0.2 \mathrm{ml} \mathrm{PCR}$ tubes

\section{SAFETY WARNINGS}

(4) Please see SDS (Safety Data Sheet) for hazards and safety warnings.

\section{BEFORE START INSTRUCTIONS}

Use RNase Zap to decontaminate all work surfaces prior to practical work, only work in a dedicated pre-PCR Area.

\section{Preparations}

\section{Bring the RNAClean XP (A63987) to $8^{\circ}$ Room temperature}

2 Ensure a chilling block to accommodate 384 -well plates is at $8^{\circ}-20^{\circ} \mathrm{C}$

3 Defrost reagents (SMARTer Stranded Total RNA-Seq Kit v2 - Pico Input Mammalian and SMART TSO Mix v2) $8^{\circ}$ On ice

4 Prepare the following program on a 384 thermal cycler:

\begin{tabular}{|l|l|}
\hline $\begin{array}{l}\text { Temp } \\
\text { eratur } \\
\mathrm{e}\end{array}$ & Time \\
\hline $72{ }^{\circ} \mathrm{C}$ & $\infty$ \\
\hline $72{ }^{\circ} \mathrm{C}$ & $3 \mathrm{~min}$ \\
\hline $42^{\circ} \mathrm{C}$ & $\infty$ \\
\hline $42^{\circ} \mathrm{C}$ & $\begin{array}{l}90 \\
\mathrm{~min}\end{array}$ \\
\hline $70^{\circ} \mathrm{C}$ & $\begin{array}{l}10 \\
\mathrm{~min}\end{array}$ \\
\hline $4^{\circ} \mathrm{C}$ & $\infty$ \\
\hline
\end{tabular}




\section{Concentration of the RNA using magnetic beads}

5 Thaw the RNA samples $8^{\circ}$ On ice (up to 2 plates of 96 samples).

Note

This protocol describes how process 2 plates of 96 samples in parallel, and uses a Gilson PlateMaster. If a PlateMaster or equivalent is not available, it is not recommended to process more than one 96 -well plate.

For 96 or fewer samples, the protocol can be executed with multichannel pipettes.

6 Add in RNAClean XP beads at $\mathbf{1 . 8}$ ratio to all RNA samples.

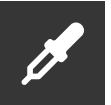

Note

NOTE: Precise measurement of the RNA volume of each sample is not crucial at this stage, as this "cleanup" has the only purpose of concentrating the RNA, and not removing unwanted oligos

\section{Incubate at $8^{\circ}$ Room temperature for 00:05:00}

8 Place the plate on magnet: allow beads to separate for 00:08:00

9 Remove supernatant and put aside in a new 96-well plate.

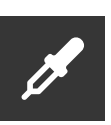

\section{Add $\triangle 200 \mu \mathrm{L} 80 \%$ ethanol to wash the beads, incubate for $00: 00: 30$}


11 Remove $\mathbf{8 0} \%$ EtOH.

12 Repeat the ethanol wash (steps $10-11$ )

\section{Note}

If two 96-well plates are being prepared together, do both ethanol washes on the 1st plate before moving to the 2 nd plate, so that the same PlateMaster tips can be used for both washes on a plate.

WARNING: Keep to time with washes on the 2 nd plate to avoid over drying beads on the $1 \mathrm{st}$ !

12.1 Add $\triangle 200 \mu \mathrm{L} 80 \%$ ethanol to wash the beads, incubate for $00: 00: 30$

\subsection{Remove $\mathbf{8 0 \%}$ EtOH.}

13 Briefly spin the plate and remove additional ethanol with fresh tips. Ensure any visible quantities of ethanol are removed.

14 Remove the plate(s) from magnet and resuspend beads in $\pi 3 \mu \mathrm{L} E B$

\section{Leave the beads in EB for 00:05:00 at $8^{\circ}$ Room temperature}


16 During the $\mathbf{5}$ mins incubation, prepare a 384-well plate containing

\section{I $0.25 \mu \mathrm{L}$ SMART Pico Oligos Mix v2}

Note

In our lab we use a Labcyte Echo 525 to dispense the Oligo Mix v2.

If accuracy of pipetting such small volume is a concern, consider scaling up the volume of the all protocol from $1 / 4$ to $1 / 2$ or more.

\section{RNA denaturation}

17 Pre-heat the thermocycler to $8^{\circ} 72^{\circ} \mathrm{C}$

18 Once the 5 mins elution time is passed, place the RNA plate on the magnet and allow beads to separate for 00:02:00

19 Transfer \& $2 \mu \mathrm{L}$ sample into the plate containing

\ $0.25 \mu \mathrm{L}$ freshly-dispensed SMART Pico Oligos Mix v2

20 Mix with PlateMaster, quickly spin down the plate.

21 Final plate for denaturation should contain:

\begin{tabular}{|l|l|}
\hline $\begin{array}{l}\text { Reag } \\
\text { ent }\end{array}$ & $\begin{array}{l}\text { Volu } \\
\text { me } \\
(\mu \mathrm{l})\end{array}$ \\
\hline $\begin{array}{l}\text { SMAR } \\
\text { TPico } \\
\text { Oligos } \\
\text { Mix } \\
\text { v2 }\end{array}$ & 0.25 \\
\hline
\end{tabular}




\begin{tabular}{|l|l|l|}
\hline RNA & 2 \\
\hline Total & $\begin{array}{l}2.25 \\
\mu \mathrm{l} / \\
\text { reacti } \\
\text { on }\end{array}$ \\
\hline
\end{tabular}

22 Place plate containing RNA and SMART Pico Oligos Mix v2 onto the pre-set thermocycler and incubate at $8^{\circ} 72{ }^{\circ} \mathrm{C}$ for $00: 03: 00$

22.1 Take the chilling block out of the freezer during the incubation

23 Immediately move samples to the chilling block and leave for 00:02:00

24 Proceed immediately to First-strand cDNA synthesis

\section{First-strand CDNA synthesis}

25 Pre-heat thermal cycler to $8^{\circ} 42^{\circ} \mathrm{C}$

26 Prepare First Strand reverse transcription mastermix by mixing the following reagents in the order

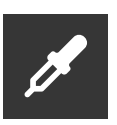
shown (no. reactions $+10 \%$ ):

\begin{tabular}{|l|l|}
\hline Reag & $\begin{array}{l}\text { Volu } \\
\text { me } \\
\text { per } \\
\text { ent } \\
\text { reacti } \\
\text { on } \\
(\mu \mathrm{l})\end{array}$ \\
\hline
\end{tabular}




\begin{tabular}{|l|l|}
\hline $\begin{array}{l}\text { 5X } \\
\text { First- } \\
\text { Stran } \\
\text { d } \\
\text { Buffer }\end{array}$ & 1 \\
\hline $\begin{array}{l}\text { SMAR } \\
\text { TTSO } \\
\text { Mix } \\
\text { v2 }\end{array}$ & 1.125 \\
\hline $\begin{array}{l}\text { RNas } \\
\text { e } \\
\text { Inhibit } \\
\text { or }\end{array}$ & 0.125 \\
\hline $\begin{array}{l}\text { SMAR } \\
\text { TScri } \\
\text { be } \\
\text { Rever } \\
\text { se } \\
\text { Trans } \\
\text { cripta } \\
\text { se }\end{array}$ & 0.5 \\
\hline Total & $\begin{array}{l}2.75 \\
\mu l\end{array}$ \\
\hline
\end{tabular}

27 Add $\triangle 2.75 \mu \mathrm{L}$ of MasterMix to each sample, mix by pipetting and then spin down the plate.

28 Place in the pre-heated thermocycler for first strand RT incubation:

$8^{\circ} 42^{\circ} \mathrm{C}$ for 01:30:00 $\rightarrow 8^{\circ} 70^{\circ} \mathrm{C}$ for 00:10:00 $\rightarrow 8^{\circ} 4{ }^{\circ} \mathrm{C}$ hold.

29 Leave samples at $8^{\circ} 4^{\circ} \mathrm{C}$ until next step.

30 SAFE STOPPING POINT!

(II) Overnight at $8^{\circ} 4^{\circ} \mathrm{C}$ or store at $8^{\circ}-20^{\circ} \mathrm{C}$

\section{PCR amplification of CDNA and library generation}

31 Prepare thermocycler in a post-PCR area for second strand amplification. 
32 Set up the PCR as follow:

\begin{tabular}{|c|c|c|}
\hline \multicolumn{2}{|c|}{ Component } & \multirow{2}{*}{\begin{tabular}{|l} 
Volu \\
me \\
per \\
reacti \\
on \\
$(\mu \mathrm{l})$ \\
\\
\\
5
\end{tabular}} \\
\hline $\begin{array}{l}\text { Samp } \\
\text { le }\end{array}$ & $\begin{array}{l}\text { First- } \\
\text { stran } \\
d \\
\text { cDNA }\end{array}$ & \\
\hline \multirow{2}{*}{$\mathrm{EACH}$} & $\begin{array}{l}\text { Index } \\
\text { ed i7 } \\
\text { prime } \\
r \\
(6.25 \\
\mu \mathrm{M})\end{array}$ & 1 \\
\hline & $\begin{array}{l}\text { Index } \\
\text { ed i5 } \\
\text { prime } \\
r \\
(6.25 \\
\mu \mathrm{M})\end{array}$ & 1 \\
\hline \multirow{3}{*}{$\begin{array}{l}\text { Mast } \\
\text { er Mix } \\
\text { (MM) }\end{array}$} & $\begin{array}{l}\text { Nucle } \\
\text { ase- } \\
\text { free } \\
\text { Water }\end{array}$ & 5 \\
\hline & $\begin{array}{l}\text { SeqA } \\
\text { mp } \\
\text { CB } \\
\text { PCR } \\
\text { Buffer } \\
(2 X) \\
\end{array}$ & 12.5 \\
\hline & $\begin{array}{l}\text { SeqA } \\
\text { mp } \\
\text { DNA } \\
\text { Polym } \\
\text { erase }\end{array}$ & 0.5 \\
\hline Total & & $\begin{array}{l}5 \\
\text { sampl } \\
\text { es }+2 \\
\text { prime } \\
\text { rs + } \\
18 \\
\text { MM = } \\
25 \mu l / \\
\text { reacti } \\
\text { on }\end{array}$ \\
\hline
\end{tabular}

PCR Setup

33 Mix by pipetting, spin down the plate and start PCR: 


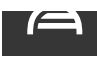

\begin{tabular}{|l|l|l|l|}
\hline Step & $\begin{array}{l}\text { Temp } \\
\text { eratur } \\
\text { e }\end{array}$ & Time & $\begin{array}{l}\text { No. } \\
\text { cycles }\end{array}$ \\
\cline { 1 - 3 } $\begin{array}{l}\text { Initial } \\
\text { Denat } \\
\text { uratio } \\
\mathrm{n}\end{array}$ & $94^{\circ} \mathrm{C}$ & $\begin{array}{l}60 \\
\text { secon } \\
\mathrm{ds}\end{array}$ & 1 \\
\cline { 1 - 3 } $\begin{array}{l}\text { Denat } \\
\text { uratio } \\
\mathrm{n}\end{array}$ & $98^{\circ} \mathrm{C}$ & $\begin{array}{l}15 \\
\text { secon } \\
\mathrm{ds}\end{array}$ & \\
\cline { 1 - 2 } $\begin{array}{l}\text { Anne } \\
\text { aling }\end{array}$ & $55^{\circ} \mathrm{C}$ & $\begin{array}{l}15 \\
\text { secon } \\
\mathrm{ds}\end{array}$ & 12 \\
\cline { 1 - 3 } $\begin{array}{l}\text { Exten } \\
\text { sion }\end{array}$ & $68^{\circ} \mathrm{C}$ & $\begin{array}{l}30 \\
\text { secon } \\
\mathrm{ds}\end{array}$ & \\
\cline { 1 - 2 } $\begin{array}{l}\text { Final } \\
\text { Exten } \\
\text { sion }\end{array}$ & $68^{\circ} \mathrm{C}$ & $\begin{array}{l}2 \\
\text { minut } \\
\text { es }\end{array}$ & 1 \\
\cline { 1 - 3 } Hold & $10^{\circ} \mathrm{C}$ & $\infty$ & \\
\hline
\end{tabular}

34 SAFE STOPPING POINT!

(3) Overnight at $8^{\circ} 4^{\circ} \mathrm{C}$ or store at $8^{\circ}-20^{\circ} \mathrm{C}$

\section{(II)}

\section{Pooling, cleanup and QC}

35 Pool in a $1.5 \mathrm{ml}$ LoBind tube equal volume of each sample to be captured together Note

NOTE: Library prepared with this protocol would yield on average $2-5 \mathrm{ng} / \mu \mathrm{l}$ : pool enough of each library for a final pool with >> $500 \mathrm{ng}$ ( $3 \mu \mathrm{l}$ per sample for a 96 -plex is usually plenty).

36 Accurately measured with a pipette the volume of the pool: this is crucial for correct size-selection of the libraries with Ampure XP beads.

37 Add $\mathbf{0 . 6 8 x}$ Ampure XP to each pool and perform a cleanup 
WARNING: The $\mathbf{0 . 6 8 x}$ ratio is to be used only on libraries from high quality RNA! If that is not the case, use $0.8 \mathrm{x}$ of Ampure XP instead.

38 Mix thoroughly either by pipetting or vortexing.

39 Incubate for $00: 05: 00$ at $8^{\circ}$ Room temperature

40 Transfer tubes to magnet and incubate for 00:08:00

41 Remove and keep supernatant in a clean tube. Do not transfer any beads in the supernatant. If this is a risk, leave $<5 \mu$ l supernatant behind with the beads.

42 Wash beads with \200 $\mu \mathrm{L} 80 \%$ ethanol . Leave for $300: 00: 30$

43 Remove and discard the supernatant.

$44 \quad$ Repeat wash with ethanol.

In 


\subsection{Wash beads with \200 $\mu \mathrm{L} 80 \%$ ethanol . Leave for $00: 00: 30$}

44.2 Remove and discard the supernatant.

45 Centrifuging tube briefly to collect any residual ethanol at the bottom of the well and pipette this off with a P10 or P20 pipette.

46 Ensure removal of all ethanol.

47 Air dry beads until the well looks dry and the beads are starting to crack.

48 Resuspend beads in a volume of EB equal to the starting pool volume or less.

Note

NOTE: Eluting in less EB will speed the drying of the pool in the SpeedVac

49 Mix by pipetting or vortexing. If vortexing, leave for $300: 02: 00$ before centrifuging.

50 Return tubes to magnet for $00: 02: 00$ 
51 Transfer the clean eluant to a fresh $1.5 \mathrm{ml}$ LoBind tube.

52 Quantify the libraries pool using Qubit® dsDNA HS Assay Kit (Cat\#: Q32854).

53 Check the size of the libraries pool on an Agilent Tapestation with a High Sensitivity D1000 Screen Tapes assay (Cat\#: 5067-5584).

54 Bring forward $500 \mathrm{ng}$ from each pool for capture (next section) and store the remaining uncaptured pool.

\section{Hybridize xGen Lockdown Probes to Target}

55 Turn on a heat block that takes $1.5 \mathrm{ml}$ tubes, and let it equilibrate to $8^{\circ} 95^{\circ} \mathrm{C}$

56 Defrost xGen ${ }^{\circledR}$ Universal Blockers (IDT), COT Human DNA (vial 1, Roche, SeqCap EZ Accessory Kit, stored at $-20^{\circ} \mathrm{C}$ ).

57 Bring the 2X Hybridization buffer (vial 5) and Hybridization Component A (vial 6) to $8^{\circ}$ Room temperature (Roche, SeqCap EZ Hybridization and Wash Kit, stored at $-20^{\circ} \mathrm{C}$ ).

58 Remove the $x$ Gen Lockdown Probes (IDT) from $-20^{\circ} \mathrm{C}$ freezer and defrost $8^{\circ}$ On ice 
The xGen Lockdown Probes are custom biotinylated oligos designed to capture cDNA libraries derived from the viral RNA.

This protocol is based on our work with HIV, and has been validated for SARS-CoV-2 using a panel of probes designed by our lab.

59 In a $1.5 \mathrm{ml}$ tube, add:

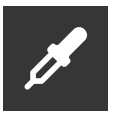

\begin{tabular}{|l|l|}
\hline $\begin{array}{l}\text { Comp } \\
\text { onent }\end{array}$ & $\begin{array}{l}\text { Amou } \\
\text { nt }\end{array}$ \\
\hline $\begin{array}{l}\text { Multip } \\
\text { lex } \\
\text { DNA } \\
\text { Samp } \\
\text { le } \\
\text { Librar } \\
\text { y Pool }\end{array}$ & $\begin{array}{l}\text { ng } \\
\text { ng }\end{array}$ \\
\hline $\begin{array}{l}\text { COT } \\
\text { Huma } \\
\text { n } \\
\text { DNA }\end{array}$ & $5 \mu l$ \\
\hline $\begin{array}{l}\text { XGen } \\
\text { B } \\
\text { Unive } \\
\text { rsal } \\
\text { Block } \\
\text { ers - } \\
\text { TS } \\
\text { Mix }\end{array}$ \\
\hline
\end{tabular}

60 Dry down the contents of the tube (libraries + COT Human DNA + Blocking Oligos) using a SpeedVac with high temperature.

61 Once the pool is completely dry, resuspend in:

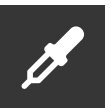

\begin{tabular}{|c|c|}
\hline $\begin{array}{l}\text { Comp } \\
\text { onent }\end{array}$ & $\begin{array}{l}\text { Amou } \\
\mathrm{nt}\end{array}$ \\
\hline $\begin{array}{l}2 X \\
\text { Hybri } \\
\text { dizati } \\
\text { on } \\
\text { buffer } \\
\text { (vial } \\
5 \text { ) }\end{array}$ & $7.5 \mu \mathrm{l}$ \\
\hline
\end{tabular}




\begin{tabular}{|l|l|}
\hline $\begin{array}{l}\text { Hybri } \\
\text { dizati }\end{array}$ & \\
on & \\
Comp & $3 \mu \mathrm{l}$ \\
onent & \\
A (vial & \\
$6)$ & \\
\hline
\end{tabular}

62 Vortex for 00:00:10 then spin down

63 Place the tube in the $88^{\circ} \mathrm{C}$ heat block for 00:10:00 to denature the DNA.

64 Spin down and transfer the content of the tube to a $0.2 \mathrm{ml} \mathrm{PCR} \mathrm{tube.}$

65 Add $\triangle 4 \mu \mathrm{L} x$ Gen Lockdown Probes and top up with water to a final volume of $\mathbf{1 5} \boldsymbol{\mu l}$.

66 Mix by pipetting.

67 The tube should contain the following:

\begin{tabular}{|l|l|}
\hline $\begin{array}{l}\text { Comp } \\
\text { onent }\end{array}$ & $\begin{array}{l}\text { Amou } \\
\mathrm{nt}\end{array}$ \\
\hline $\begin{array}{l}\text { Multip } \\
\text { lex } \\
\text { DNA } \\
\text { Samp } \\
\text { le } \\
\text { Librar } \\
\text { y Pool }\end{array}$ & $\begin{array}{l}\text { ng* } \\
\text { ng }\end{array}$ \\
\hline $\begin{array}{l}\text { Cot-1 } \\
\text { DNA }\end{array}$ & $5 \mathrm{\mu g}^{\star}$ \\
\hline
\end{tabular}




\begin{tabular}{|c|c|}
\hline $\begin{array}{l}\text { xGen } \\
\text { § } \\
\text { Unive } \\
\text { rsal } \\
\text { Block } \\
\text { ers - } \\
\text { TS } \\
\text { Mix }\end{array}$ & $2 \mu l^{\star}$ \\
\hline $\begin{array}{l}2 X \\
\text { Hybri } \\
\text { dizati } \\
\text { on } \\
\text { Buffer } \\
\text { (vial } \\
\text { 5) }\end{array}$ & $7.5 \mu \mathrm{l}$ \\
\hline $\begin{array}{l}\text { Hybri } \\
\text { dizati } \\
\text { on } \\
\text { Comp } \\
\text { onent } \\
\text { A (vial } \\
\text { 6) }\end{array}$ & $3 \mu \mathrm{l}$ \\
\hline $\begin{array}{l}\text { xGen } \\
\text { Lockd } \\
\text { own } \\
\text { Probe } \\
\text { s }\end{array}$ & $4 \mu \mathrm{l}$ \\
\hline $\begin{array}{l}\text { Nucle } \\
\text { ase- } \\
\text { Free } \\
\text { Water }\end{array}$ & $0.5 \mu l$ \\
\hline Total & $15 \mu \mathrm{l}$ \\
\hline
\end{tabular}

*Dried in the SpeedVac

68 Incubate hybridization reaction at $8^{\circ} 47^{\circ} \mathrm{C}$ in a thermocycler (lid heated at $8^{\circ} 57^{\circ} \mathrm{C}$ ) for 믐 04:00:00 (or Overnight).

69 If proceeding after a $4 \mathrm{~h}$ hybridization, change the heat block's temperature used in step 63 to $8^{\circ} 47^{\circ} \mathrm{C}$

70 Allow time to equilibrate to the set temperature. 


\section{Prepare wash buffers}

71 If proceeding after an overnight hybridization, turn on a heat block that takes $1.5 \mathrm{ml}$ tubes to $8^{\circ} 47^{\circ} \mathrm{C}$, and let it equilibrate to the set temperature.

$722 \mathrm{~h}$ before the end of the hybridization, dilute 10X Wash Buffers (I, II, III and Stringent) and 2.5X Bead Wash Buffer (Roche, SeqCap EZ Hybridization and Wash Kit, stored at $-20^{\circ} \mathrm{C}$ ) to create $\mathbf{1 X}$ working solutions.

\begin{tabular}{|l|l|l|l|}
\hline & $\begin{array}{l}\text { Buffer } \\
(\mu \mathrm{l})\end{array}$ & $\begin{array}{l}\text { Water } \\
(\mu \mathrm{l})\end{array}$ & $\begin{array}{l}\text { Final } \\
\text { volum } \\
\mathrm{e}(\mu \mathrm{l})\end{array}$ \\
\hline 10X Wash Buffer I (vial 1) & 33 & 297 & 330 \\
\hline $10 X$ Wash Buffer II (vial 2) & 22 & 198 & 220 \\
\hline 10X Wash Buffer III (vial 3) & 22 & 198 & 220 \\
\hline $\begin{array}{l}\text { 10X Stringent Wash Buffer (vial } \\
\text { 4) }\end{array}$ & 44 & 396 & 440 \\
\hline 2.5X Bead Wash Buffer (vial 7) & 220 & 330 & 550 \\
\hline
\end{tabular}

73 For each capture reaction, preheat the following wash buffers to $8^{\circ} 47^{\circ} \mathrm{C}$ in the heat block:

- 1X Stringent Wash Buffer (all)

- I $110 \mu \mathrm{L} 1 \mathrm{X}$ Wash Buffer I

74 Equilibrate buffers at $8^{\circ} 47^{\circ} \mathrm{C}$ for at least 02:00:00 before starting wash steps of the captured DNA (section "Wash streptavidin beads to remove unbound DNA" below).

\section{Prepare the Streptavidin Dynabeads}

75 Allow Dynabeads $\mathbf{M - 2 7 0}$ Streptavidin (stored at $4^{\circ} \mathrm{C}$ ) to equilibrate to $8^{\circ}$ Room temperature for 00:30:00 before use ( 30minutes before the end of the hybridization).

76 Mix the beads thoroughly by vortexing for $00: 00: 15$ 
77 Aliquot $\triangle 100 \mu \mathrm{L}$ streptavidin beads per capture into a single $1.5 \mathrm{ml}$ tube (i.e., for 1 capture use $\square$ $100 \mu$ l beads, for 2 captures use $200 \mu$ l beads, etc.).

78 Place the tube in a magnetic separation rack. Allow the beads to separate from the supernatant. Carefully remove and discard the clear supernatant ensuring that all of the beads remain in the tube.

79 Add I $200 \mu \mathrm{L}$ 1X Bead Wash Buffer per $100 \mu$ l beads. Vortex for $00: 00: 10$

80 Place the tube back in the magnetic rack to bind the beads. Allow the beads to separate from the supernatant. Carefully remove and discard the clear supernatant ensuring that all of the beads remain in the tube.

81 Repeat wash with $1 X$ Bead Wash Buffer.

81.1 Add $\triangle 200 \mu \mathrm{L} 1 \mathrm{X}$ Bead Wash Buffer per $100 \mu$ l beads. Vortex for $00: 00: 10$

81.2 Place the tube back in the magnetic rack to bind the beads. Allow the beads to separate from the supernatant. Carefully remove and discard the clear supernatant ensuring that all of the beads remain in the tube.

82 After removing the buffer following the second wash, add $1 \mathrm{X}$ the original volume of beads of $\mathbf{1 X}$ Bead Wash Buffer (i.e., for $100 \mu$ l beads, use $100 \mu$ l buffer) and resuspend by vortexing. 
83 Transfer $\triangle 100 \mu \mathrm{L}$ of the resuspended beads into a new $0.2 \mathrm{ml}$ tube for each capture reaction.

84 Place the tube in a magnetic rack to bind the beads. Allow the beads to separate from the supernatant. Carefully remove and discard the clear supernatant ensuring that all of the beads remain in the tube.

\section{Bind hybridized target to the streptavidin beads}

85 Take the samples pool from $\equiv 9$ go to step \#68 out of the thermocycler (do not stop the program!) quickly spin down and transfer to the tube containing prepared streptavidin beads.

86 Mix thoroughly by pipetting up and down 10 times.

87 Place the tube back into the thermal cycler set to $8^{\circ} 47^{\circ} \mathrm{C}$ and incubate for $00: 45: 00$ (set heated lid at $8^{\circ} 57^{\circ} \mathrm{C}$ ) to bind the DNA to the beads.

88 Vortex the tube for 00:00:03 every $15 \mathrm{~min}$ to ensure that the beads remain in suspension.

\section{Wash streptavidin beads to remove unbound DNA}

89 Take the samples out of the thermal cycler and add $\triangle 100 \mu \mathrm{L}$ pre-heated $1 \mathrm{X}$ Wash Buffer I to the tube and vortex for $00: 00: 10$ to mix.

90 Spin down and transfer the mixture to a fresh low-bind $1.5 \mathrm{ml}$ tube. 
91 Place the tube in the magnetic separation rack. Allow the beads to separate from the supernatant. Using a pipette, remove the supernatant containing unbound DNA and discard.

92 Add $\triangle 200 \mu \mathrm{L}$ preheated $1 \mathrm{X}$ Stringent Wash Buffer and pipette up and down 10 times to mix. Incubate on the heat block at $8^{\circ} 47^{\circ} \mathrm{C}$ for $00: 05: 00$

93 Place the tube in the magnetic separation rack. Allow the beads to separate from the supernatant. Using a pipette, remove the supernatant containing unbound DNA and discard.

94 Repeat wash with preheated 1X Stringent Wash Buffer.

94.1 Add $\triangle 200 \mu \mathrm{L}$ preheated $1 X$ Stringent Wash Buffer and pipette up and down 10 times to mix.

Incubate at $8^{\circ} 47^{\circ} \mathrm{C}$ for $00: 05: 00$

94.2 Place the tube in the magnetic separation rack. Allow the beads to separate from the supernatant. Using a pipette, remove the supernatant containing unbound DNA and discard.

95 Add $\triangle 200 \mu \mathrm{L}$ room temperature $1 \mathrm{X}$ Wash Buffer I and vortex for $\bigcirc 00: 02: 00$ to mix.

96 Place the tube in the magnetic separation rack. Allow the beads to separate from the supernatant. Using a pipette, remove the supernatant and discard. 
97 Add $\triangle 200 \mu \mathrm{L}$ room temperature $1 \mathrm{X}$ Wash Buffer II and vortex for 00 001:00 to mix.

98 Place the tube in the magnetic separation rack. Allow the beads to separate from the supernatant. Using a pipette, remove the supernatant and discard.

99 Add $\triangle 200 \mu \mathrm{L}$ room temperature $1 \mathrm{X}$ Wash Buffer III and vortex for 00:00:30 to mix.

100 Place the tube in the magnetic separation rack. Allow the beads to separate from the supernatant. Using a pipette, remove the supernatant and discard.

101 Remove the tube from the magnetic rack and add $\triangle 25 \mu \mathrm{L}$ Nuclease-Free Water to resuspend the beads. Mix thoroughly by pipetting up and down 10 times.

Note

Do not pellet or remove the beads: The post-capture PCR is done on the beads

102 SAFE STOPPING POINT!

(7) Overnight at $8^{\circ} 4^{\circ} \mathrm{C}$ or store at $88^{\circ}-20^{\circ} \mathrm{C}$

\section{Post-capture PCR}

103 Thaw the KAPA HiFi HotStart ReadyMix and the Post-LM-PCR Oligos from the SeqCap EZ Accessory Kits v2 (stored at $-20^{\circ} \mathrm{C}$ ). 
104 Set up the PCR as follow:

\begin{tabular}{|l|l|l|}
\hline EACH & $\begin{array}{l}\text { Comp } \\
\text { onent }\end{array}$ & $\begin{array}{l}\text { Volu } \\
\text { me }\end{array}$ \\
\hline & $\begin{array}{l}\text { Captu } \\
\text { red } \\
\text { library } \\
\text { on } \\
\text { beads }\end{array}$ & 25 \\
\hline & $\begin{array}{l}\text { KAPA } \\
\text { HiFi } \\
\text { HotSt } \\
\text { art } \\
\text { Ready } \\
\text { Mix } \\
\text { (Roch } \\
\text { e) }\end{array}$ & 50 \\
\hline MASTER MIX & $\begin{array}{l}\text { Post- } \\
\text { LM- } \\
\text { PCR } \\
\text { Oligos } \\
182, \\
5 \mu M \\
\text { (Roch } \\
\text { e) }\end{array}$ & 5 \\
\hline & $\begin{array}{l}\text { Nucle } \\
\text { ase } \\
\text { free } \\
\text { water }\end{array}$ & 20 \\
\hline & & $\begin{array}{l}75 \\
+25 \\
\text { library } \\
=100 \\
\mu l / \\
\text { reacti } \\
\text { on }\end{array}$ \\
\hline & \\
\hline
\end{tabular}

PCR Setup

105 PCR incubation:

\begin{tabular}{|l|l|l|l|}
\hline Step & $\begin{array}{l}\text { Temp } \\
\text { eratur } \\
\mathrm{e}\end{array}$ & Time & $\begin{array}{l}\text { No. } \\
\text { cycles }\end{array}$ \\
\hline $\begin{array}{l}\text { Initial } \\
\text { Denat } \\
\text { uratio } \\
\mathrm{n}\end{array}$ & $98^{\circ} \mathrm{C}$ & $\begin{array}{l}45 \\
\text { secon } \\
\text { ds }\end{array}$ & 1 \\
\cline { 1 - 2 } $\begin{array}{l}\text { Denat } \\
\text { uratio } \\
\mathrm{n}\end{array}$ & $98^{\circ} \mathrm{C}$ & $\begin{array}{l}15 \\
\text { secon } \\
\text { ds }\end{array}$ & \\
\hline $\begin{array}{l}\text { Anne } \\
\text { aling }\end{array}$ & $60^{\circ} \mathrm{C}$ & $\begin{array}{l}30 \\
\text { secon } \\
\mathrm{ds}\end{array}$ & 12 \\
\cline { 1 - 2 } $\begin{array}{l}\text { Exten } \\
\text { sion }\end{array}$ & $72^{\circ} \mathrm{C}$ & $\begin{array}{l}30 \\
\text { secon } \\
\text { ds }\end{array}$ \\
\end{tabular}




\begin{tabular}{|l|l|l|l|}
\hline $\begin{array}{l}\text { Final } \\
\text { Exten } \\
\text { sion }\end{array}$ & $72{ }^{\circ} \mathrm{C}$ & $\begin{array}{l}1 \\
\text { minut } \\
\mathrm{e}\end{array}$ & 1 \\
\hline Hold & $10^{\circ} \mathrm{C}$ & $\infty$ & \\
\hline
\end{tabular}

106 SAFE STOPPING POINT!

(II) Store at $8^{\circ}-20^{\circ} \mathrm{C}$ or $8^{\circ} 4^{\circ} \mathrm{C}$

107 Perform Ampure XP clean-up with $\mathbf{0 . 6 8 x}$ ratio and elute into $\triangle 20 \mu \mathrm{L}$

Note

WARNING: The $\mathbf{0 . 6 8 x}$ ratio is to be used only on libraries from high quality RNA! If that is not the case, use $0.8 \mathrm{x}$ of Ampure XP instead

108 SAFE STOPPING POINT!

(11) Store at $8^{\circ}-20^{\circ} \mathrm{C}$ or $8^{\circ} 4^{\circ} \mathrm{C}$

\section{Captured Pool QC and 10nM-ing}

109 Quality check the captured pool using Qubit and Tapestation.

Ná Note

Pools concentrations is highly variable and dependent on samples viral load $(<1 \mathrm{ng} / \mu \mathrm{l}$ is NOT to be considered a fail!)

110 Tapestation profile should have a long tail, but it's dependent of the quality of the starting RNA. For high quality RNA, after two $0.68 x$ Ampure XP cleanups, one pre- and one post-capture, the profile should look like this: 


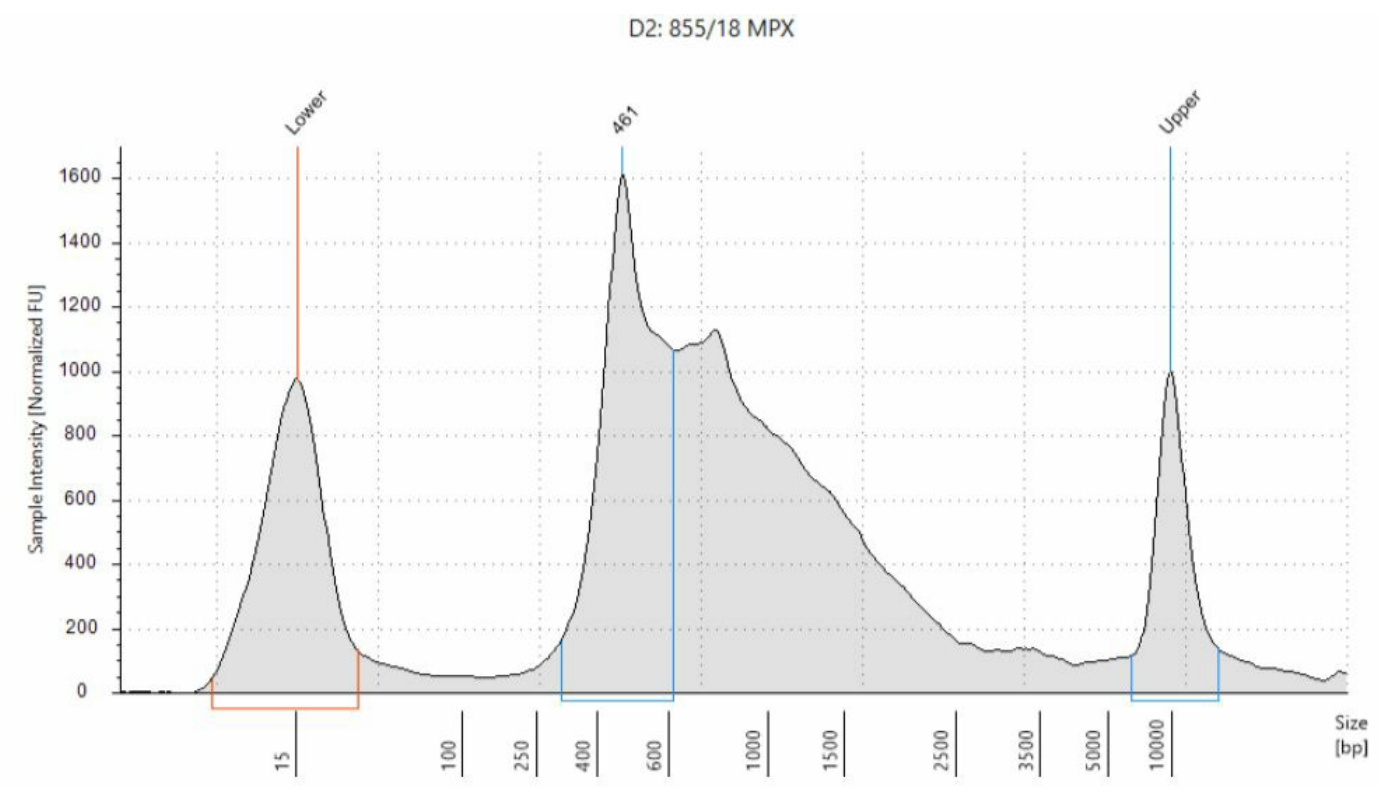

